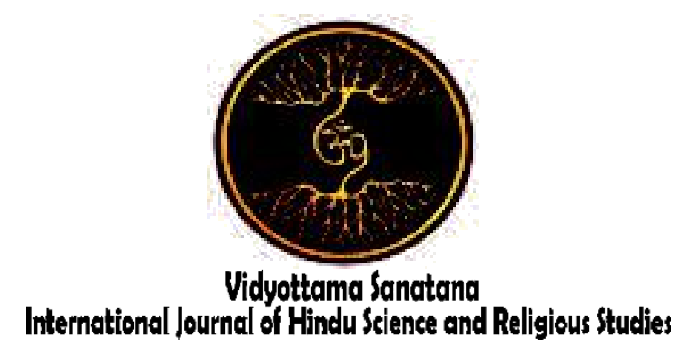

Vol. 3 No. 2 October 2019

\title{
SASOLAHAN SANGHYANG ONCESRAWA AT PENATARAN SASIH TEMPLE, DESA PAKRAMAN PEJENG TAMPAKSIRING DISTRICT, GIANYAR REGENCY
}

\author{
By: \\ I Nyoman Linggih \\ Institut Hindu Dharma Negeri Denpasar \\ E-mail : manlinggih@gmail.com
}

Received: July 24, 2019

Accepted: September 28, 2019

Published: October 31, 2019

\begin{abstract}
The Sanghyang Oncesrawa dance is not just a mere spectacle dance, this dance is in a state of unconsciousness, dancing on a burning fire and even though there are no signs of burning the body parts of the dancers. This dance is not a show or show off strength. The Sanghyang Oncesrawa dance is motivated by the loss of a beloved horse, the king of Bali, namely Sri Gajah Waktera with the title Sri Asta Sura Ratna Bumi Banten, a white hairy horse with a very powerful black tail named kuda oncesrawa. King Bedahulu's favorite horses disappeared and never came again. To commemorate the horse named Oncesrawa, the Sanghyang Oncesrawa Dance was performed in the Sasih Penataran Temple. This dance is classified as the art of sacred dance and when dancing mattress, moves agile (dangkrikdingkrik = Balinese language) like horse movements. The research was conducted to multiply, raise, explore, socialize, religious dances, especially the Sanghyang Oncesrawa Dance, which so far still many people do not understand correctly. Qualitative research was carried out in the Sasih Penataran Temple through a cultural approach with data sources from figures, dance artists, pemangku, serati, library and photos. The results of the research analysis showed that the Sanghyang Oncersrawa dance is a sacred dance that is only danced on piodalan / large ceremonies (Ngusaba Nyatur), dances on coals in a trance state, bringing pratima / arca / pralingga of Sanghyang Oncesrawa, dances in a row while kicking a burning fire. The Sanghyang Oncesrawa dance has a function, namely; religious, sanctification, social and aesthetic. Sanghyang Oncesrawa dance has religious, sanctification, social, and aesthetic meaning.
\end{abstract}

Keywords: Dance and Sanghyang Oncesrawa 


\section{INTRODUCTION}

Bandem asserted, in Bali there were almost no religious ceremonies that were finished without participating in the dance performance (in Yasa, 2018: 1). One dance that is closely related to the ceremony is the Sanghyang Oncesrawa Dance. The Sanghyang Oncesrawa dance is classified as a Wali (sacral) dance, when the dancer is unconscious, dances on a burning fire and there is no sign of burning any part of the body of the dancers. This dance is not a show or show off strength. The Sanghyang Oncesrawa dance is only found in the Penataran Sasih Temple. According to Gusti Niyang Mangku (interview, 11 June 2017) said Ida Betara only danced when a large ceremony was held, and even then if $\mathrm{He}$ wanted $($ Betara mekayunan $=$ Balinese $)$, and if $\mathrm{He}$ was not pleased, even though the ceremony was great, Sanghyang Oncesrawa would not dance. This phenomenon is believed by the public, that the dancers conceded Hyang (spirit) and danced according to the character of the spirit that possessed him.

This study aimed to describes, analyzes, socializes, and preserves the Sanghyang Oncesrawa Dance as a religious dance art that is the increasingly fading dance. This study used several theories namely; Theory of Functional Structuralism by Claude LeviStrauss (in Sutrisno, 2005: 125). Theory of Symbolic Meanings by; Koentjaraningrat, 1990: 235, Pelly, 1994: 5-6, and Sutrisno, 2005: 125 . It is expected that the results of this study can provide positive added value to the knowledge of supporting communities, as well as the wider community, especially in the development of IPTEKS (science knowledge, technology, and art); furthermore, as a guideline for subsequent academics.

\section{METHOD}

This study was a qualitative research, with a culture-oriented approach to the foundation of thinking to understand a meaning, which includes phenomenological symptoms, symbolic, cultural, ethno- methodology interactions or art criticism (Endraswara, 2008: 252). So the approach taken was theological and social humanist, with the technique of "Random Sampling" (randomly) where the subject to be investigated consists of a number of individuals representing a larger number, randomly selected. The object of research in this case was people who are seen to know and understand about the Sanghyang Oncesrawa Dance in the Penataran Sasih Temple. In this study used several data collection techniques such as: (1) Observation, (2) Interview (Interview); and (3) Documentation; and (4) This study carried out various actions such as intensive data extraction, data categorization, data compilation, data interpretation (interpretive qualitative), namely interpretation using knowledge, ideas, and concepts that researchers understood related to the problems examined.

\section{RESULT AND DISCUSSION}

Sasolahan (Dance) Sanghyang

Oncesrawa can be described on several concepts, namely; Solah, which is from the basic Balinese word, that is, solah has several meanings, including; laksana = behavior, and igel or dance (Simpen, 1985: 207). From the basic word solah, it developed into several forms of word modification, namely masolah which means ngigel or dancing, nyolahang which means acting, and sasolah, which means performing. Another view states, that solah is behavior, character, ne melah nyandang tulad = good behavior should be imitated . Masolah = behave; Melah = behave well. So masolah = dancing; Ida ring RRI, which means He dances on RRI. Nyolahang = dancing, so sesolahang is a way of dancing a dance (Warna, 1978: 662). In the Indonesian Old Javanese Dictionary, Sasolah is behavior (Zoetmulder, 2006: 1113). Sasolahan is reaffirmed, "Motion as the raw material for Sasolahan is a reflection of the movements in the human psyche, in other words motion is used by humans as the main important tool to express their desires" (Soedarsono, 1977: 
2). So Sasolahan is a spontaneous reflection of movements that exist in the human soul, this implies that these movements occur suddenly without realizing it by the dancer, therefore the movement is subconscious. Such movements are referred to as the dance of Ida Betara / Ida Betara Masolah. Sasolahan of Ida Betara (sacred dance) is a dance whose dancers are unconscious.

Sanghyang Oncesrawa can be divided into two words, namely; Sanghyang and Oncesrawa. Sanghyang comes from the word "Sang" which means "Lingga" as for mentioning "Sang Bhima", "Sang Arjuna", and others. The word "Sang" also means "Jajeneng Kasta Prasanghyang". "Hyang" means "God" or "He" 2010: 497). So, "Sanghyang" can be interpreted as "the name or identity of God in the manifestation of "Him". The word "Sang Hyang" is "the article for God and its manifestations; for example: Sang Hyang Widhi, Sang Hyang Brahma. While the word "Sangiang" can be interpreted as "the sacred dance that dancer possesed while dancing on fire", such as: sangiang dedari, sangiang jaran (Warna, 1991: 606).

"... Sanghyang is one of Bali's Wali arts, and is a cultural heritage of the Para-Hindus. Unlike other dances, Sanghyang is held at certain times and cannot be done by other people who are not Sanghyang family. Sanghyang, which is only shown when needed, especially during outbreaks of disease, is usually staged a month later, waiting until the outbreak of the disease disappears. After the disease is eradicated, then Sanghyang is not shown again, up to a year then (Bandem, 1982: 124).

Bandem emphasized again that Kerawuhan Sasolahan Sanghyang can be achieved by deception, inhaling frankincense smoke, singing Gending Sanghyang, Sanghyang performances are very diverse, each has an element of improvisation in accordance with the culture that developed around it (Bandem, 1996: 8) while "Oncesrawa" is "the name of a flying horse (in fairy tales)" (Warna, 1991: 476). In the developing folklore in the community of
Pejeng that, "Oncesrawa" relates to the name of the horse owned by the King of Ancient Bali (Ruma, interview, 6 August 2017). So "Sasolahan (Dance) Sanghyang Oncesrawa" is a Sanghyang dance called Sanghyang Oncesrawa, danced by a number of dancers in a trance state that is only danced at Penataran Sasih Temple, Pejeng, Tampak Siring, Gianyar.

This study was qualitative research, by Endraswara, 2008: 252 with a cultural approach oriented to the foundation of thinking to understand a meaning, including phenomenological symptoms, symbolic, cultural, ethno-methodology or artistic interactions, with data collection techniques such as: (1) Observation, (2) Interviews; and (3) Documentation; and (4) Literature.

\section{FORMS OF SASOLAHAN SANGHYANG ONCESRAWA \\ 1. History of Sasolahan Sanghyang Oncesrawa}

As a reflection of this description, it is necessary to say a little about mythology of the Sanghyang Oncesrawa Dance in piodalan at Pura Panataran Sasih, Pejeng Village. It is said that in Bali there was a king named Sri Gajah Waktera (Dalem Bedaulu), with the title Sri Astasura Ratna Bumi Banten who was said to be a brave and very powerful person.

The king had a favorite horse named Oncesrawa which was considered to be magic. It had white fur with a black tail that reaches the ground long. Sri Gajah Waktera released the horse Oncesrawa, each area passed by the horse no one dared to disturb him, then the area was under the king's control.

The long-awaited horse Oncesrawa did not return and was considered lost. Sri Gajah Waktera sent all his people to look for the horse. Finally Ki Tunjung Biru lived in Tenganan, managed to find the Oncesrawa horse on a hillside east of the village of Tenganan now but was already dead. The area where the Oncesrawa horse was found is now known as "Jaran Batu". To commemorate the Kuda Oncesrawa, 
Sanghyang Oncesrawa Dance was held. (Karianto and Pleret, interview, 10 June 2017).

\section{Procession of Sanghyang Oncesrawa}

The Sanghyang Oncesrawa staging procession begins with the mapekeling, Nedunang, and Ngantukang processes. (Desak Niang Ayu, interview, June 18, 2017).

\section{a. Matur Pakeling}

Starting from the mapekeling process on the Palinggih Padma Kurung which is located in the jeroan of Pura Panataran Sasih, which is led by Jero Mangku by doing worship, the process is continued to carry out a purification process or ngiasin Sanghyang Oncesrawa Dance. After the offerings have all been carried out, then continue with Nusdus Arca Sanghyang Oncesrawa (Putra Pemayun, interview, 11 June 2017).

\section{b. Nedunan Sasolahan Sanghyang Oncesrawa}

Nudus procession begins with the cak dance. Cak dance in a circle while releasing the words "cak cak cak cak" in greetings. While waiting for the Sanghyang Oncesrawa Dancing nadi or trance, the Cak Dance and sanghyang singing continue to be sung. Likewise the composer will sing the song of nurunan through penudusan stage. Arca Sanghyang Oncesrawa is smoked with pasepan. Singers or composers repeat Sanghyang Oncesrawa dance songs aiming to invite the spirits of the gods and widyadara widyadari or Angels to descend from the heaven. Not long after the Sasolahan Sanghyang Oncesrawa danced unconsciously or Kasurupan, as can be seen in the photo below.

Photo Sanghyang Oncesrawa is dancing

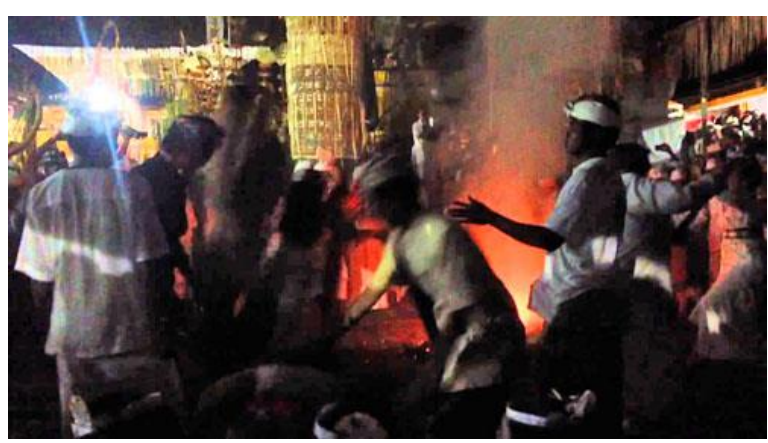

\section{c. Ngantukan Sanghyang Oncesrawa}

The end of the Sanghyang Oncesrawa Dancing procession was marked by the dancers entering the Arca of Sanghyang Oncesrawa into Sangku or place of holy water that had been provided. The Singers will sing the song of pengluhur. Jero Mangku will sprinkle Tirtha or holy water to Prelingga Sanghyang Oncesrawa. It is strung together by sprinkling Tirtha to the trance dancers until he is awake, and finally continued by mesineb ceremony. This event is accompanied by offering the banten pangeluhur by Jero Mangku.

\section{Tools of Sasolahan Sanghyang Oncesrawa}

The tools or equipment used in the Sasolahan Sanghyang Oncesrawa include: Horse head masks, palm leaves, penyalin, gongseng, coconut shells, tirta, flowers, and banten or offerings.

\section{Song of Sasolahan Sanghyang Oncesrawa}

\section{a. The Song of Nusdus or Nuntun}

The song that is sung during Sasolahan Sanghyang Oncesrawa performance as follows:

\section{Kukus Arum \\ Kukus arum \\ Gandane dupa mirik sumirit \\ Sembar wangi ring kasore \\ Jebug arum saking tawang \\ Ya saking tawang \\ Kaselir, kesir-kesir angin \\ Rawuh maring kadewatan \\ Juru nadi oncer sarwa \\ Ya oncer sarwa \\ Ya luwih goban nyane becik \\ Penganggene sarwa luwih \\ Ambra murub pakuranyab.}

After the song is sung then, the Sanghyang Oncesrawa got up while prancing up and down, trod on, or bathed the embers running like the movements of a horse. 


\section{b. The Song of Mesolah}

The example of the song that is used for nyolahang Sanghyang Oncesraw, is as follows:

Jaran Putih
Kasireg tumbragin banyu
Ikang banyu nunas ica
Tepuk api keceburin
Macan rakrik, bangun ngelur
makekipu
Makeskesan jalan mula
Ijarin malabuh geni
Singa warak
Gajah lembune macan rakrik,
bangun ngelur makekipu
Makeskesan jalan mula
Ijaran malabuh geni.

\section{c. The Song of Ngantukan or Ngeluhuran}

The end of the procession of Masolah Sanghyang Oncesrawa is marked by the dancers entering the Sanghyang Oncesrawa statue into the sangku or place of holy water that had been provided. Juru Gending will sing the song of pengluhur. The song for Ngantukan or Ngeluhuran Sanghyang Oncesrawa is:

\section{Gending Panyineb}

Ketut-ketut Nyoman bangun

Madingehang munyin sulinge di jaba

Kenken-kenken munyin sulinge di jaba Rindit-rindit gegupekan metimpal kempul

Nyen kal orta mengupekin

Ngurah Agung uli dijero pemecutan

\section{Music or Gamelan Accompaniment in Sasolahan Sanghyang Oncesrawa.

On Sasolahan Sanghyang

Oncesrawa, there is no musical instrument used. All processions from beginning to end are only accompanied by Cak Dance and

sanghyang song, can be seen in the photo below

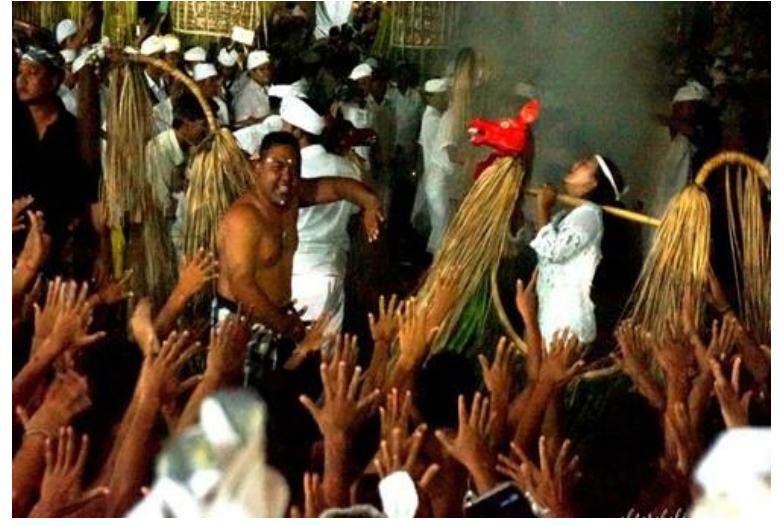

PhotoCak Dance and Gending Sanghyang as the Accompaniment of Sasolahan

Sanghyang Oncesrawa on piodalan at Penataran Sasih Temple

\section{Function Of Sasolahan Sang Hyang Onceswara}

\section{a. Religious Function}

Koentjaraningrat (1987: 57), states that religious and religious ceremonies are an important element for social life. The religious aspect is an important aspect of human life starting from the human belief in the power that is outside the human self, as well as the supernatural power. Besides that religion begins, when humans are fascinated by magical powers and there is an interest in uniting with the unseen.

Moreover, in the book of Bhagavdgita it is expressly stated that Sang Hyang Widhi Wasa is supernatural and that occultation is God Himself, as in the following verse:

Avinasi tu tad viddhi yena sarvam idam tatam,

Vinasam avyayasya na kascit kartum aharti.

(Bhagavadgita.II.17)

Translation:

Know that I am Supernatural and that all of this cannot be destroyed.

Against this eternal existence, no one can destroy it (Radhakrishnan, 2010: 129).

The verse in the Bhagavadgita mentioned above provides an understanding that the supernatural power is Sang Hyang 
Widhi Wasa and that power cannot be destroyed. In other words this supernatural power is eternal. Besides that occultation is one of the aspects of Sang Hyang Widhi Wasa, mentioned in Tattwajñana as follows:

... Atmikatattwa is Sadasiwatattwa who is "Utaprota" in Mayatattwa (Acetana). Uta means God is supernatural in Mayatattwa like fire in wood. Prota means that God is like a brilliant gem in Mayatattwa, ... (Tim Penyusun, 2005: 18).

Likewise, Sasolahan Sanghyang Oncesrawa on piodalan in Penataran Sasih Temple, Pejeng Village is very close to the supernatural power. According to Desak Niang Made Ayu (interview, August 6, 2017), at the time of Sasolahan Sanghyang Oncesrawa didusdus, the dancers will feel that there is a great power penetrating into them, and immediately the people around them appear small.

\section{b. Purification Function}

In human beings or Bhuwana Alit, there are two forces, these two forces always exist and are side by side; therefore, it is very important to balance these two dimensions of power towards balance or harmonization. The negative forces that dominate Bhuwana Agung and Bhuwana Alit will not cause balance. This imbalance will have implications for the emergence of various diseases (merana). Describing Samkya Darsana's disease states that there are three sources of illness that bring suffering, namely:

Adhyatmika, namely suffering caused by viruses, germs and the like.

Adhidaivika, which is a disease that comes from nature, weather and others.

Adhibauthika, which is a disease that comes by animals and that emerges from birth (Sivananda, 2003: 193).

The three diseases that have implications for suffering are the result of the imbalance between the two negative and positive forces. Based on this, it is very important to trace or understand the power through the Sasolahan Shangyang Oncesrawa, so Bhuwana Agung and Bhuwana Alit becomebalance. According to Putra Pamayun (interview, August 6, 2017), during the Sanghyang Oncesrawa dance in Penataran Sasih Temple, the dance movements followed the natural rhythm, while bathed in fire. The dancers who are in trance of Sanghyang Oncesrawa while wagging their tails made from ambu. It is much believed by the local community as a negative power neutralizer towards balance.

\section{c. Social Function}

Humans are actually social beings who cannot live alone. Social interaction is needed by humans so that humans can live, because humans live need each other and depend on each other. Not only to human beings, but also to human nature, humans are interdependent, because humans will not be able to live without nature and vice versa. Many fields of activity can show and establish good social relations, especially in Bali where there are many activities that can create a sense of social solidarity. Bali itself is known as a customary system called Pakraman Village, of course, as a place of social interaction between Krama Bali or Balinese people and as Hindu detention (Atmaja, 2010: 196).

All activities especially religious activities are always carried out within the scope of Pakraman Village which causes harmony between Balinese Hindu communities. As Wiana said (2004: 78), that Hindu social harmony in Bali cannot be separated from religious activities carried out in every village on the basis of the teachings of Hinduism. Based on this, many religious activities in Bali have a function as a medium in fostering social harmony.

\section{d. Aesthetics Function}

Djelantik (1999: 9), states that aesthetics is a science that studies everything related to beauty, learns all aspects of what is called beauty. Art can only be understood in 
terms of the social meaning contained in it (Gie, 1996: 38). Donder (2005: 33), aesthetics can be interpreted as a beauty that stimulates and encourages people to be creative and be dynamic to achieve inner satisfaction and sharpen their intuition. Whatever language is given by experts, almost everything leads to a discourse concerning the sense of beauty that makes us happy, amazed, fascinated, excited, and excited. Bandem (1996: 18).

Hindu aesthetics is essentially a perspective on beauty (lango) which is bound by Hindu values based on the teachings of the Vedic scriptures. There are a number of concepts that might be an important foundation of Hindu aesthetics. The concepts in question include the concept of chastity, the concept of truth, and the concept of balance. In Hinduism it is called the term Three Wisesa, namely:

a.Sivam (The concept of purity) is essentially concerned with divine values which also include yajna and taksu.

b.Satyam (truth) includes the value of honesty and sincerity. In accordance with the teachings of Hinduism, offerings and yajña carried out by the Hindu community should be carried out with full honesty, sincerity, and sincere intention.

c.Sundaram (Beauty), which is in the context of a special theory (local theory) as described above, then new aesthetic satisfaction will be fulfilled if there has been harmony (Djelantik, 1999: 20)

So, Sasolahan Sanghyang Oncesrawa at Penataran Sasih Temple can be said to have an aesthetic function. Sanghyang Oncesrawa has a conception of Satyam, Siwam, Sundaram. Ida Sang Hyang Widhi Wasa is the most beautiful and the source of all beauty. In the Vedic holy library, Ida Sang Hyang Widhi Wasa described in the form of Shiva Nataraja with His cosmic dance is said to be the creator of music and dance as well as the creator of the great art (Saraswati, 2005: 299). For details, see Photo below.
Photo Sasolahan Sanghyang Oncesrawa

while dancing on coals

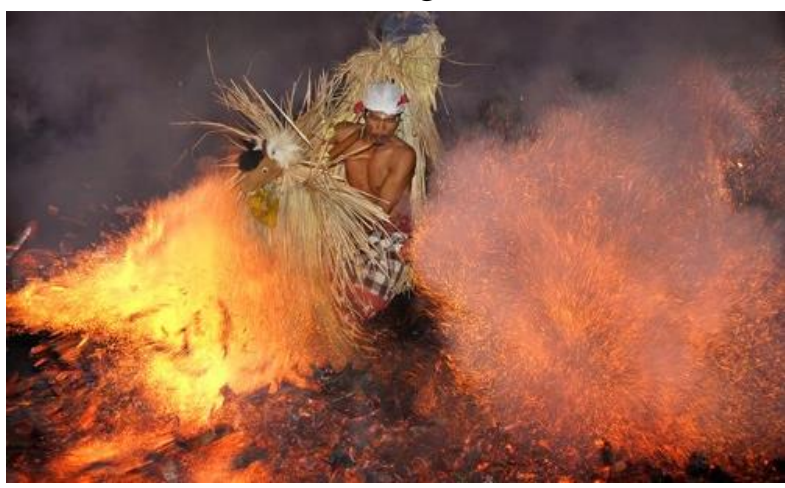

(Documentation 2016)

\section{Meaning Of Sasolahan Sanghyang Oncesrawa}

The meaning implied cannot be separated from the teachings of Hinduism which is known to have elasticity which always emphasizes the meaning of Tattwa which includes religious, sanctification, social, and aesthetic meanings.

\section{a. Religious Meaning}

The religious meaning in the Sanghyang Oncesrawa dance is very important first to understand the terminology of religion that is identical to tattwa in Hinduism. According to Subagiasta (2007: 6), Tattwa derives from the word Tat which means essence, truth, reality, essence of teachings, and the word Twa means nature. So, the word Tattwa is the essence or truth, an element both real and unreal or the essence of Hyang Widhi. Nurkancana (2005: 5), states that Tattwa means essence, or real reality. Likewise Tattwa is knowledge of the true nature or reality of Hyang Widhi. Tattwa implicitly refers to the principles or essence of true truth. That true truth according to Gandhi (in Suwantana, 2006: 9), is called the Almighty God.

According to Desak Niang Made Ayu (interview, August 6, 2017), when Jero Tapakkan began to enter supernatural power, a great deal of energy was felt throughout the body, and the body became lighter and lighter, the body did not burn and felt hot by fire, and human around him looked small as if he felt big. As explained by the eight 
omnipotence of God or called Astaaiswarya in the following Wrehaspati Tattwa:

Hana anima nagaranya, hana laghima nagaranya, hanamahima nagaranya, hana prapti nagaranya, hana prakamya ngaranya, hana isitva ngaranya, hana vasitva nagaranya, hana yatrakamavasitva nagaranya...,(Wrehaspati Tattwa. 66) Translation:

There is something called anima (Lord Shiva's strength can be as small as possible), laghima (as light as possible), mahima (as large as possible beyond everything), prapti (always success), prakamnya (manifest of all desires), isitva (regulator), vasitva (omnipotence) and yatrakamavasitva (almighty) and it is eight aisvarya or supernatural powers of God .... (Putra, 1998: 68)

As in Isa Upanishads mention the following: Iśavāsyam idam sarvam yat kim ca jagatyām jagat, tena tyaktena bhuñjithā, mā gradhah kasyasvid dhanam.(Iśa Upanisad, I.1)

Translation:

Know all this that anything that moves in this world, everything is wrapped up by God. Because of that, find your happiness in the release and do not want something that is the right of others (Radhakrisnan, 2010: 437).

\section{b. Sanctification Meaning}

According to Putra, (2001: 9), upacara or ceremony derives from the word "upa" which means "relating to", and "cara" that comes from the word "car" which means motion then gets the ending "a" into a noun which means movement. So the upacara or ceremony is anything related to movement or activity, or in other words the ceremony is a movement (execution) of a yajna. In general, the upacara or ceremony is in the form of material which is also called "banten", Upacara means "approaching", also means "respect" the core of the ceremony is tattwa is indeed an activity that draws people and their natural environment, with each other and with God. Approaching to the natural environment aims to build a Bhutahita nature which means a prosperous environment (Wiana, 2004: 37-38). The key is any type of ritual offered is certainly based on a pure and sincere heart without expecting a reward (Subagiasta, 2006: 38). So the word upacara or ceremony means movement or activity around the life of mankind, or the activities of mankind in efforts to connect themselves with God.

Sasolahan Sanghyang Oncesrawa is equipped with ceremonies and upakara as a means of the people in presenting the holy spirit so that it is pleasing to possessed prelingga Sanghyang Oncesrawa. By using the appropriate means of banten at the Sasolahan Sanghyang Oncesrawa procession a kind of feeling that is calm and sacred in oneself and so are other societies.

In Lontar Yajna Prakerti, it is stated as follows:

Sehananing babanten pinaka raganta twi,

Pinaka warna rupaning Ida Bhatara, pinaka anda bhuwana.

Translation:

All bebanten is the symbol of the human and a symbol of content of the universe (Wiana, 2004: 11).

\section{c. Social Meaning}

Religious activities for Balinese people especially Hindus cannot be separated from ethics or Susila itself. Ethics plays an important role in Hindus connecting themselves with God. In connecting with God, Hindus can take many ways, as stated in the Bhagavadgita as follows:

Ye yathā mām prapadyante tāms tathaiva bhajāmy aham,

Mama vartmānuvarthante manusyāh pārtha sarvaśyah. (Bhagavadgita, IV. 11)

Translation:

Whatever way people worship $\mathrm{Me}$, on the same path I fulfill his desires, $\mathrm{O}$ Partha, because all the paths they take, all are My ways (Maswinara, 1999: 234). 
Ethics or Susila in Hinduism itself can be termed as a rule of good behavior (Atmaja, 2010: 11). In line with that, Ngurah, (1999: 1), explained that ethics not only has one or two people. However, ethics belongs to every community group, with ethics, community groups are expected to have a meaningful system to regulate living together.

\section{d. Aesthetics Meaning}

Hindu aesthetics is basically a perspective on the feeling of beauty (lango or kalangwan), a term used by ancient kawi, which is seen by the meaning of Hinduism based on the teachings of the Vedic scriptures. In connection with this description, then several concepts are the important foundation of Hindu aesthetics, namely the concept of chastity, the concept of truth and the concept of balance. In the Hindu aesthetic concepts in Bali, especially in the three wisesa concepts, namely: satyam (truth), siwam (purity), sundaram (beauty) (Djelantik, 1999: 58). Sasolahan Sanghyang Oncesrawa begins with gending Sanghyang which always sings with melodious rhythms, so that people are hypnotized by the beauty of the song. Song or Gending itself is actually already in the Vedas, as in the following mantram:

Gayo sasra wartani meaning that We sing Sama Weda mantras in thousands (Titib, $2003:$ 54).

Reg Weda Book Mandala II states the importance of vocal art in carrying out religious ceremonies, such as in the following mantram:

Pradaksinid abhi grnanti karavo
Vayo vadanta rtuthā sukhantayah
Ubhe vacau vadati sāmagā iva
Gayatram ca traistubhyam cānu
rájati. (Reg Weda II.43.1)
Translation:
May the birds of conscience guide us
forever in proclaiming about the
journey in accordance with the
environment, such as a hymn singer
who cleverly states about the two
types of praise such as the saman

singer after mastering the metrics of gayatri, usnik, tristyubh, and jagati (Titib, 2003 : 335).

Sasolahan Sanghyang Oncesrawa is a dance that reflects natural movements as a life cycle based on rtam. Likewise a movement that brings out the beauty that comes from Rasasvada. Rasasvada is an expression of taste that arises from within that is synonymous with beauty and art. Bharata Muni (in Watra, 2007: 21), states that the problem of art is the problem of "taste" which is one aspect of Natyasastra which is extorted from the Catur Vedic book. Sasolahan Sanghyang Oncesrawa can create beauty because in the dance nine rasasvada bhava appear, according to Yudabhakti (in Watra, 2007: 23), mentioning Nine Bhava include: (1) Srnggara, namely love, (2) Hasya namely pride, (3) Karuna, which is love or sadness, (4) Raudra, which is anger, (5) Wira, namely feeling strong, (6) Bhayanaka, feeling of danger, (7) Bhibatsa, feeling of beauty, (8) Adbhuta, feeling shocked (9) Santa is the culmination of a sense of freedom. Looking at the nine bhava, it can be said that Sanghyang dance is a dance that can create beauty, magic and religion. According to Ruma (interview, August 6, 2017), mentioning at the time of Sanghyang Oncesrawa dance, the Sanghyang Oncesrawa's movement seems to imply a feeling of sadness, enthusiasm, anger, love, pride, seeing danger, powerful and finally a movement full of calm.

\section{CONCLUSION}

Sanghyang Oncesrawa is carried out based on the history of a horse named Oncesrawa. This thick white-haired horse is King Bedahulu's favorite horse that disappeared and never came again. To commemorate the horse named Oncesrawa, Sasolahan Sanghyang Oncesrawa is carried out in the Penataran Sasih Temple. This dance is classified as the art of sacred dance and when dancing, the dancers are possessed, moving agile on a horse-like movement. 
Sanghyang Oncesrawa dance has a function, namely; religious, sanctification, social and aesthetic. Sasolahan Sanghyang Oncesrawa has religious, sanctification, social, and aesthetic meaning.

\section{REFERENCES}

Aryasa, I Made. 1999. Dimensi Seni Sakral Agama Hindu. Surabaya :Paramita.

Aryasa, Wayan Madra. 1996. Meteri Pokok Seni Sakral, Direktorat Jendral Bimbingan Masyarakat Hindu Dan Buddha Jakarta

Atmaja, Nengah Bawa. 2010. Ajeg Bali Gerakan Identitas Kultural dan Globalisasi. Yogyakarta : LKIS.

Bandem, I Made.1982. Ensiklopedi Tari Bali. Denpasar : Akademi Seni Tari Indonesia (ASTI)

Bandem, I Madem,1996.Etnologi Tari Bali.Yogyakarta : Kanisius (Anggota IKAPI).

Dibia, I Wayan. 2000. Makalah Seni Sakral, Disampaikan Dalam Penataran Dosen Agama Hindu Sekolah Tinggi Agama Hindu Negeri Denpasar.

Djelantik, A.A. Made.1999. Estetika Sebuah Pengantar. Bandung : Masyarakat Seni Pertujukan Indonesia

Donder, I Ketut. 2005. Kosmologi Hindu: Penciptaan, Pemeliharaan, dan Peleburan, serta Penciptaan Kembali Alam semesta. Surabaya : Paramita.

Endraswara, Suwardi. 2008. Metodelogi Penelitian Kebudayaan. Jogyakarta : Gajah Mada University Press.

Gie, The Liang. 1996. Filsafat Seni. Yogyakarta : Pusat Belajar Ilmu Berguna.

Goris. R. 2012. Sifat Religius Masyarakat Pedesaan di Bali.Denpasar : Udayana University Press.

Kaplan, David. 1999. Teori Budaya. Jogyakarta : Pustaka Pelajar.

Koentjaraningrat. 1987. Manusia dan Kebudayaan di Indonesia. Jakarta : Djambatan.

Mantra, Ida Bagus.1997. Landasan Kebudayaan Bali. Denpasar : Yayasan Dharma Sastra.
Maswinara. 1999. Bhagavadgita. Surabaya : Paramita.

Narayana, Sri Swami. 2006. Wacana Mucim Panas. Jakarta : Sai Books Trust.

Ngurah, I Gusti Made. dkk. 1999. Buku Pendidikan Agama Hindu Untuk Perguruan Tinggi. Surabaya : Paramita

Nurkacana. 2005. Tattwa dan Fisafat Hindu. Denpasar : Manikgeni.

Putra, I Gusti Agung Gede,1998. Wrehaspati Tattwa. Surabaya : Paramita.

Radhakrishnan, Sarvepali. 2010. UpanisadUpanisad Utama. Surabaya : Paramita.

Saraswati, Sri Chandrasekharendra. 2005. Peta Jalan Veda. Jakarta : Media Hindu.

Simpen, I Wayan AB.1958. Sejarah Bali. Denpasar : Pustaka Balimas.

Sivananda, Sri Svami. 2003. Intisari Ajaran Hindu. Surabaya : Paramita.

Soedarsono. 1977. Estetika Sebuah Pengantar Bagi Studi Seni Tari. Yogyakarta : Akadmi Seni Tari Indonesia.

Subagiasta, I Ketut. 2007. Tattwa Hindu. Surabaya : Paramita.

Sutrisno, Mudji dan Hendar Putranto. 2005. Teori-Teori Kebudayaan.

Yogyakarta : Kanisius

Suwantana, I Gede. 2006. Gandhi da Doa. Denpasar : Ashram Gandhi Puri.

Tim Penyusun, 2015.Sri Haji Jaya Pangus. Dinas Kebudayaan dan Pariwisata Gianyar Bekerja Sama Dengan IHDN Denpasar : Kabupaten Gianyar

Tim Penyusun,2010.Kamus Besar Bahasa Indonesia. Departemen PendidikanDan Kebudayaan : Balai Pustaka

Titib, I Made, 2003. Teologi dan SimbolSimbol dalam Agama Hindu. Surabaya : Paramita.

Triguna, Ida Bagus Yuda. 2000. Teori Tentang Simbol. Denpasar : Widya Dharma. 
Watra, I Wayan. 2007. Filsafat Seni Sakral dalam Kebudayaan. Surabaya : Paramita.

Wiana, I Ketut. 2004. Bagaimana Umat Hindu Menghayati Tuhan. Jakarta : Pustaka Manikgeni
Zoetmulder. 2006. Kamus Jawa Kuna Indonesia. Jakarta : Gramedia Pustaka Utama 